\title{
PERANCANGAN SISTEM INFORMASI \\ PENGELOLAAN DATA TEMU HILANG KENDARAAN DI POLRESTABES BANDUNG
}

\author{
Dani Hamdani ${ }^{1}$, Rima Rahmayanti ${ }^{2}$ \\ ${ }^{1}$ Program Studi Sistem Informasi, Fakultas Teknik, Universitas Widyatama \\ ${ }^{2}$ Program Studi Manajemen, Fakultas Bisnis \& Manajemen, Universitas \\ Widyatama \\ Jl. Cikutra 204 A, Bandung 40125 \\ dani.hamdani@widyatama.ac.id ${ }^{1}$, rima.rahmayanti@widyatama.ac.id ${ }^{2}$
}

\begin{abstract}
ABSTRAK
Kepolisian Negara Republik Indonesia adalah lembaga pemerintah yang bertugas menjaga keamanan dan ketertiban masyarakat, serta pelayanan kepada masyarakat. Perkembangan teknologi informasi saat ini sangat diharapkan untuk meningkatkan kegiatan pelayanan polisi kepada masyarakat. Salah satu jenis layanan yang diharapkan akan dibantu oleh kemajuan teknologi informasi adalah mencari keluhan atau informasi tentang kendaraan yang hilang. Karena laporan dari kendaraan yang hilang Seringkali subjek pengaduan masyarakat selama periode Beberapa tahun, tetapi dari penulis diperoleh data menunjukkan bahwa ada kesenjangan antara jumlah kendaraan yang hilang dengan sejumlah kendaraan telah ditemukan. Dan sejauh ini, masyarakat juga kurang mendapatkan informasi tentang kendaraan yang hilang dari data yang telah ditemukan. Penelitian ini memiliki tujuan untuk membuat website portal yang bisa menjadi solusi untuk masalah pelaporan kendaraan hilang. Metode yang digunakan dalam penelitian ini adalah metode penelitian tindakan yang lebih terfokus pada pemecahan masalah yang reflektif dan kolaboratif. Sedangkan metode pengembangan sistem yang digunakan adalah metode prototyping. alat pemodelan sistem informasi yang digunakan adalah diagram konteks, data flow diagram, dan diagram hubungan entitas. Dari hasil penelitian menunjukkan Beberapa fakta seperti penyebab kurangnya kendaraan hilang diselesaikan dan menciptakan sistem pencarian informasi kendaraan yang hilang untuk membantu polisi untuk menyebarkan informasi mengenai status kendaraan yang hilang.
\end{abstract}

Kata Kunci: kendaraan, hilang, temu, polisi

\section{PENDAHULUAN}

Perkembangan teknologi informasi yang cenderung semakin maju mendorong setiap instansi public atau perusahaan untuk tetap mengikuti perkembangannya. Terutama berkenaan dengan perkembangan teknologi informasi yang ada hubungannya dengan kegiatan instansi tersebut.

Kepolisian Negara Indonesia adalah sebuah lembaga yang bertanggungjawab dalam memelihara kemananan dan ketertiban masyarakat,menegakkan hokum, dan memberikan perlindungan, pengayoman serta pelayanan kepada masyarakat.

Perkembangan teknologi informasi sangat diharapkan untuk dapat memberikan kontribusi yang cukup berarti dalam meningkatkan kegiatan pelayanan terhadap masyarakat, salah satu kasus yang sering menjadi bahan aduan masyarakat adalah kasus pencurian kendaraan bermotor baik roda dua maupun roda empat. 
Kasus pencurian kendaraan bermotor bukanlah kasus yang baru bagi institusi kepolisian. Setiap harinya selalu ada laporan kehilangan kendaraan karena pencurian. Berikut penulis sajikan data angka kehilangan kendaraan bermotor di wilayah kota besar Bandung pada tahun 2013-2015:

Tabel 1 Data Kendaraan Hilang/Dicuri Tahun 2013-2015 di Kota Bandung

\begin{tabular}{|c|l|c|c|}
\hline No & Tahun & \multicolumn{2}{|c|}{ JumlahRanmor } \\
\cline { 3 - 4 } & & R2 & R4 \\
\hline 1 & 2013 & 970 & 164 \\
\hline 2 & 2014 & 1166 & 155 \\
\hline 3 & 2015 & 2809 & 166 \\
\hline & Jumlah & 4.945 & 485 \\
\hline
\end{tabular}

Sumber : Satlantas dan Satreskrim Polrestabes Bandung, 2016

Diduga jumlah sebenarnya lebih banyak, karena data diatas adalah data yang hanya dilaporkan saja. Beberapa kasus pencurian kendaraan dapat terungkap apabila adanya cukup bukti dan ketanggapan masyarakat untuk melaporkan kasus pencuriannya secara jujur dan detail.

Tabel 2 Data Kendaraan ditemukan Tahun 2013-2015 di Kota Bandung

\begin{tabular}{|c|l|c|c|}
\hline \multirow{2}{*}{ No } & Tahun & \multicolumn{2}{|c|}{ JumlahRanmor } \\
\cline { 3 - 4 } & & R2 & R4 \\
\hline 1 & 2013 & 132 & 8 \\
\hline 2 & 2014 & 112 & 10 \\
\hline 3 & 2015 & 116 & 45 \\
\hline & Jumlah & 450 & 62 \\
\hline
\end{tabular}

Sumber : Satlantas dan Satreskrim Polrestabes Bandung, 2016

Dari tabel 2 kita dapat melihat bahwa kesenjangan kendaraan yang dicuri dan ditemukan sangat jauh. Selama ini kasus kehilangan kendaraan bermotor dapat terungkap dari:

1. Hasil penindakan pemeriksaan kendaraan di jalan yaitu pada saat operasi kelengkapan kendaraan dan surat-surat.

2. Hasil informasi pengaduan masyarakat.

3. Hasil lidik dan pengungkapan dari kepolisian.

Namun Hal yang disayangkan adalah kurangnya informasi kepada masyarakat secara online jika kendaraan yang dihasilkan dari penindakan kendaraan dapat ditemukan.

Oleh Karena itu, penelitian ini bertujuan untuk membuat sebuah sistem informasi manajemen yang dapat membantu mempermudah proses penyampaian informasi terkait temu hilang kendaraan kepada masyarakat luas, sehingga dengan adanya system tersebut diharapkan pelayanan polisi menjadi lebih baik lagi.

\section{KAJIAN PUSTAKA}

2.1 Sistem Informasi Manajemen

Definisi sistem informasi manajemen menurut Jogiyanto Hartono (2000:700) Sistem Informasi Manajemen adalah kumpulan dari interaksi sistem-sistem informasi yang 
bertanggung jawab mengumpulkan dan mengolah data untuk menyediakan informasi yang berguna untuk semua tingkat manajemen didalam kegiatan perencanaan dan pengendalian.

Pada dasarnya sistem informasi mempunyai tiga kegiatan utama yaitu: menerima data sebagai masukan, kemudian memprosesnya dengan melakukan perhitungan, penggabungan unsur-unsur data dan akhirnya dapat diperoleh informasi yang diperlukan sebagai keluaran. Prinsip tersebut berlaku baik bagi sistem informasi manual maupun sistem informasi modern dengan penggunaan perangkat komputer

Sistem informasi manajemen yang efektif menurut Raymond Coleman dalam Moekijat (1991:40) adalah bahwa sistem tersebut dapat memberikan data yang cermat, tepat waktu, dan yang penting artinya bagi perencanaan, analisis, dan pengendalian manajemen untuk mengoptimalkan pertumbuhan organisasi. George M. Scott yang diterjemahkan oleh Budiman (2001:100), mengemukakan Sistem Informasi Manajemen adalah serangkaian sub-sistem informasi yang menyeluruh dan terkoordinasi dan secara rasional terpadu yang mampu mentransformasi data sehingga menjadi informasi lewat serangkaian cara guna meningkatkan produktivitas yang sesuai dengan gaya dan sifat manajer atas dasar kriteria mutu yang telah ditetapkan.

\subsection{Pelaporan}

Reporting (pelaporan) menurut Luther M. Gullick dalam bukunya Papers on the Science of Administration merupakan salah satu fungsi manajemen berupa penyampaian perkembangan atau hasil kegiatan atau pemberian keterangan mengenai segala hal yang bertalian dengan tugas dan fungsi-fungsi kepada pejabat yang lebih tinggi. baik secara lisan maupun tertulis sehingga dalam penerimaan laporan dapat memperoleh gambaran bagaimana pelaksanaan tugas orang yang member laporan. Selain itu, pelaporan merupakan catatan yg memberikan informasi tentang kegiatan tertentu dan hasilnya disampaikan ke pihak yang berwenang atau berkaitan dengan kegiatan tertentu.

Laporan berisi informasi yang didukung oleh data yang lengkap sesuai dengan fakta yang ditemukan. Data disusun sedemikian rupa sehingga akurasi informasi yang kita berikan dapat dipercaya dan mudah dipahami.

Berdasarkan pendapat tersebut, dapat disimpulkan bahwa laporan adalah suatu bentuk penyampaian informasi yang didukung oleh data yang lengkap sesuai dengan fakta sehingga informasi yang diberikan dapat dipercaya serta mudah dipahami. Dalam penyampaiannya, laporan dapat bersifat lisan maupun tertulis.

Pelaporan tidak lepas dari pencatatan sebab sebelum diadakannya pelaporan dari bawahan kepada atasannya atau dari suatu intansi daerah ke instansi pusat haruslah dilakukan pencatatan mengenai hal yang akan dilaporkan kemudian dilakukan perekapan kemudian dilaporkan.

\section{METODE PENELITIAN}

\subsection{Metode Analisis dan Pengembangan Sistem}

Untuk menyelesaikan penelitian ini, penulis menggunakan metode penelitian Action Research. Penelitian tindakan (action research) merupakan penelitian pada upaya pemecahan masalah atau perbaikan yang dirancang menggunakan metode penelitian tindakan yang bersifat reflektif dan kolaboratif.

Sedangkan untuk metode pengembangan sistem, penulis memilih prototyping method. Prototyping adalah satu dari sekian banyak metode pengembangan software yang biasanya paling banyak digunakan. Karena tingginya interaksi antara pengembang dan pelanggan selama proses pembuatan software. 


\subsection{Metode Pengumpulan Data}

Sedangkan dalam pengumpulan data penulis menggunakan beberapa teknik sebagai berikut:

1) Wawancara/interview

Wawancara atau interview adalah teknik pengumpulan data dengan mengadakan tanya jawab secara langsung kepada pihak yang berwenang.

2) Survei/Observasi

Survei atau observasi adalah cara mengumpulkan data secara langsung kepada instansi yang bersangkutan. Dalam hal ini penulis melakukan survei pada bagian Lalu Lintas, IT, dan Humas Dan Masyarakat.

\section{3) Studi Pustaka}

Studi Pustaka merupakan metode pengumpulan data dengan cara mempelajari dan mencatat data dokumen yang tertulis dari buku-buku dan literatur yang berhubungan dengan penelitian ini.

\section{HASIL PENELITIAN}

Rancangan sistem informasi manajemen pelaporan temu hilang kendaraan yang telah dibuat digambarkan dalam diagram konteks serta data flow diagram.

\section{1) Diagram Konteks}

Diagram konteks adalah sebuah diagram yang digunakan untuk menggambarkan keseluruhan sistem secara garis besar serta aliran data yang masuk ataupun keluar pada sistem tersebut.

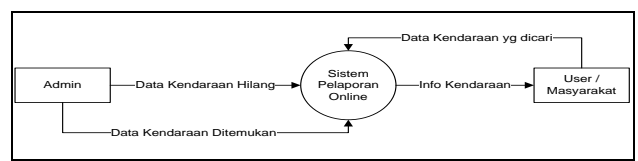

Gambar 1 Diagram Kontek

2) Data Flow Diagram (DFD)

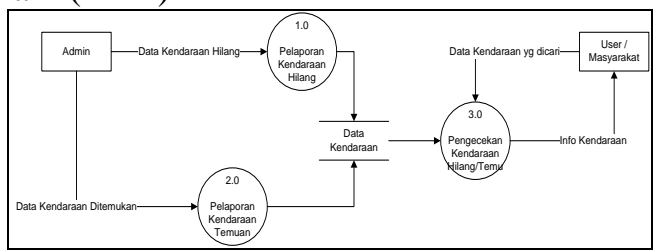

Gambar 2 Data Flow Diagram

3) Tampilan Aplikasi

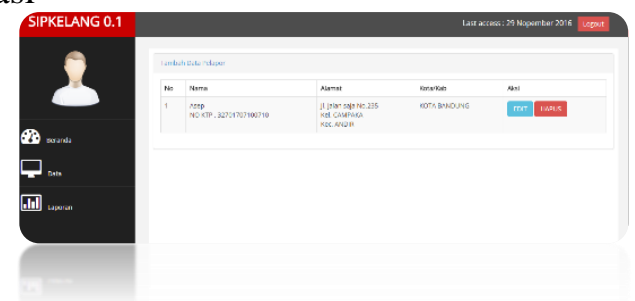

Gambar 3 Halaman Data Pelapor 


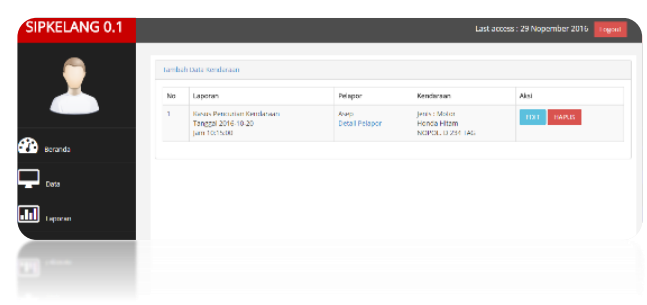

Gambar 4 Halaman Data Kendaraan

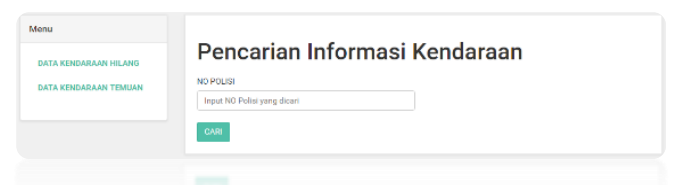

Gambar 5 Halaman Depan (Publik)

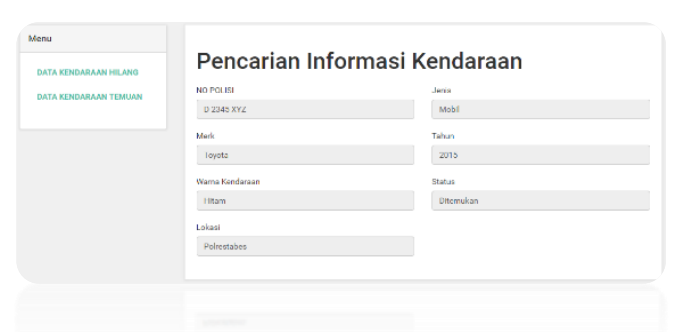

Gambar 6 Halaman Detail

\section{KESIMPULAN}

Berdasarkan hasil penelitian, dapat disimpulkan bahwa :

1) Pada tahap implementasi, masyarakat dapat mengetahui tentang status kendaraan yang hilang. Begitu juga polisi dapat lebih mudah memperbarui status kendaraan dari menjadi hilang ditemukan

2) Pada tahap pengujian yang dilakukan oleh polisi, untuk fungsi telah dianggap sesuai dengan kebutuhan. Hanya saja sistem ini masih memiliki kelemahan dalam hal tampilan/interface.

3) Hasil penelitian ini sebagai versi revisi dari aplikasi yang hilang temu (hiltem) di Korlantas Mabes Polri yang telah disusun untuk lebih memungkinkan orang untuk menemukan laporan kendaraan hilang secara cepat.

\section{DAFTAR PUSTAKA}

[1] Jogiyanto HM , "Analisis dan Desain Sistem Informasi", 2005.

[2] Kristanto, Andri, Perancangan Sistem Informasi dan Aplikasinya, Gava Media. Yogyakarta, 2008.

[3] McLeod Jr., R. \& Schell, G.P. ,'Sistem Informasi Manajemen”, 2007 edisi ke-10 terjemahan Ali A.Y. \& Afia R.F. (2008). Jakarta : Salemba Empat.

[4] Mulyanto, Agus. 2009. Sistem Informasi Konsep \& Aplikasi. Pustaka Pelajar. Yogyakarta.

[5] Satlantas \& Satreskrim Polrestabes Bandung, 2016. 